\title{
The Palestinian Resistance: Nonviolent Praxis in a Gramscian
}

\section{Paradigm}

\section{La resistencia palestina: praxis noviolenta desde un paradigma gramsciano}

\author{
Ayman Talal Yousef \\ Arab American University of Palestine, Palestine \\ Luca Foschi ${ }^{*}$ \\ University of Cagliari, Italy \\ Diego Checa Hidalgo \\ University of Granada, Spain \\ https://orcid.org/0000-0002-3269-0240
}

Artículo de investigación

Fecha de recepción: 29 de febrero de 2020 Fecha de aceptación: 21 de abril de 2020

\section{Para citar este artículo:}

Yousef, A., Foschi, L. y Checa Hidalgo, D. (2020). The Palestinian Resistance: Nonviolent Praxis in a Gramscian Paradigm. Campos en Ciencias Sociales, 8(2), 73-110. DoI: https://doi.org/10.15332/25006681/6013

\footnotetext{
Ayman Talal Yousef is professor of international relations and conflict resolution at the Arab American University, Palestine. He is the Board's Director of Policy and Conflict Resolution Studies Center there. He has written books and articles in international refereed journals dealing with IR and peace studies. He has been awarded a wide range of awards including Fulbright fellowship, Erasmus plus, DAAD, and Marie Curie awards. E-mail: ayman.yousef@aauj.edu

* Luca Foschi is a PhD from the University of Cagliari, faculty of Political Science. He graduated in journalism at the "London School of Journalism" and attended the "War reporter course Maria Grazia Cutuli" at the University of Tor Vergata, Rome. As a freelance journalist he has written from Lebanon, Palestine, Jordan, Syria, Turkey, Iraq, Iran, and Afghanistan. E-mail: lucafoschi@live.com

... Diego Checa Hidalgo is a PhD from the University of Granada. He is lecturer in Contemporary History and researcher in the Peace and Conflicts Institute in the University of Granada. His research projects have been focused on Latin America, the Middle East, and Southern Europe. E-mail: diegoch@ugr.es
} 


\begin{abstract}
This article analyses the praxis of nonviolent resistance in Palestine through the lens of Gramsci. First, it begins with a historical inquiry into the major phenomena of the Palestinian resistance tradition. Its nonviolent expressions are highlighted in order to prove their continuity as well as their effectiveness, focusing on three uprisings of the national movement where this form of resistance was deployed: the Arab revolt, the First Intifada, and the Al Aqsa Intifada. Then, it presents the framework of the theoretical tradition of nonviolent struggle in order to interpret Palestinian popular resistance actions and strategies. Finally, these forms of resistance are embedded, and subsumed, in a Gramscian alternative hegemonic paradigm, so as to enhance the discussion around an organic nonviolent strategy of political resistance.
\end{abstract}

Keywords: nonviolence, civil resistance, popular resistance, Palestine, Gramsci.

\title{
RESUMEN
}

Este artículo analiza la praxis de la resistencia no-violenta en Palestina a través de la lente de Gramsci. El artículo inicia con una investigación histórica sobre los principales fenómenos de la tradición de resistencia palestina, cuyas expresiones noviolentas se destacan para demostrar su continuidad y su efectividad, centrándose en tres levantamientos del movimiento nacional donde se desplegó esta forma de resistencia: la Revuelta Árabe, la Primera Intifada y la Intifada de Al Aqsa. Más adelante se presenta el marco de la tradición teórica de la lucha noviolenta para interpretar las acciones y estrategias de resistencia popular palestina. Finalmente, estas formas de resistencia se integran e incluyen en el paradigma hegemónico alternativo de Gramsci, con el fin de avivar la discusión en torno a una estrategia orgánica noviolenta de resistencia política.

Palabras clave: noviolencia, resistencia civil, resistencia popular, Palestina, Gramsci. 


\section{INTRODUCTION}

Since its first epiphanies at the beginning of the xxth century, popular resistance has passed through many phases and experiences that have profoundly characterised the Palestinian cause ${ }^{1}$. Along with the paroxysms represented by the 1936 revolt during the British Mandate period and the 1987 and 2000 Intifadas, the Palestinian revolution has gone through numerous episodes that have left several lessons inscribed in the matrix of the collective memory as entangled elements of an increasingly conscious, organic strategy. In the last ten years, the adoption of the nonviolent popular resistance concept has been the result of several factors and variables which must be critically identified. First among such turning points is the experience of the Second Intifada, which escalated the military confrontation with the Israeli occupying forces and contributed to the massive destruction and reoccupation of the Palestinian cities and communities, whose administration had been modelled according to the Oslo Agreement signed by the PLO and Israel in 1993. The psychological and material damage inflicted by the Israeli armed forces on the Palestinian citizens and institutions has been extensive. During the prolonged confrontation, previous political gains were dissipated due to the military operations waged by the Palestinian military corps against Israeli targets, both military and civilian.

During the confrontation, the Apartheid Wall (the West Bank Barrier in Israeli parlance) was built inside the West Bank territories, separating them completely from the 1948 Palestinian lands. The wall encroached on and snatched important

1 The term popular resistance is commonly understood in Palestinian politics as equivalent to civil resistance or nonviolent struggle. Civil resistance is a type of political action involving "the sustained use of methods of nonviolent action by civilians engaged in asymmetric conflicts with opponents not averse to using violence to defend their interests" (Schock, 2013, p. 277). It is a collective phenomenon that encompasses multiple forms of social, psychological, economic and political action that do not resort to the threat or use of violence and that are used to challenge a specific power, force, policy or regime, with the aim of satisfying the objectives of a wide sector of society or citizens (Randle, 1994, pp. 9-10). There are hundreds of non-violent methods available to civil resistance (Sharp, 1973; López Martínez, 2017). Civil resistance is known with synonyms such as "nonviolent resistance", "nonviolent struggle", "nonviolent revolutions", "people power", and it is equivalent to the Gandhian "satyagraha” (Carter, 2012). Among those who practice this type of resistance we can differentiate between those who resort to it in a pragmatic or strategic way and those who develop it based on its moral principles (Vinthagen, 2015). Civil resistance processes were present in many liberation struggles across the world in recent contemporary history (Bartkowski, 2013). 
portions of Palestinian territories, already eroded from within by the Israeli settlements, responsible, since 1967, for the disruption of the pre-existing demographic, geographical, and economic balance. There has been a massive protest from international civil society against the move. This has also triggered a response from Israeli activists, including those of the leftist movements, who have begun to consider themselves as an integral part of a liberation process, marked by a vigorous moral dimension and capable of capturing international public opinion.

The Palestinian Authority has contributed to the development of the popular resistance paradigm. Particularly after the political split with the Hamas-ruled Gaza Strip in 2007, it has focused on institutionalisation, sustainable development, transparency and raising the banner of nonviolent resistance as a lever for negotiation. In the last five years, the Palestinian strategy, in order to deal with the occupation, has changed considerably and become definable by three major variables: nonviolent popular resistance; institutionalisation and sustainable development; involvement of international public opinion and solidarity. As we hope to demonstrate, several factors have prevented this strategy from becoming effective.

The nonviolent resistance approach is today more necessary than ever, as the diplomatic horizon with the Israeli counterpart has frozen and, in parallel with this, divisions within the Palestinian front have weakened the leadership in putting forward its demands for freedom, independence and statehood. By cultivating the idea of the absence of a serious and reliable Palestinian partner in the negotiations, the rightwing government led by Benjamin Netanyahu has managed to further compromise the peace process. Such diplomatic sabotage has enhanced the possibility for Israel to preserve the stall in the negotiations while allowing the illegal colonisation of the West Bank and East Jerusalem to reach a degree that could dangerously lead to the impracticability of the two-state solution.

These are elements that could not easily be reversed in the future if negotiations were to be reactivated. Popular resistance has also attracted the interest of Palestinian academics, inspired by a long international tradition of struggle against oppression. 
In shifting towards a nonviolent paradigm, the popular movements have increasingly begun to look at such figures as Gandhi, Martin Luther King, and Nelson Mandela, whose examples of struggle in India, the United States, and South Africa have encouraged many studies and democratic experiments.

Although armed struggle remains an essential component of almost all Palestinian parties and movements, nonviolent resistance is increasingly perceived among the population, the intellectual class, and political cadres as an organic strategy to be employed in the attempt to end the Zionist colonial occupation. This study begins with a historical inquiry into the major phenomena of the Palestinian resistance tradition. Its nonviolent expressions are highlighted in order to prove their continuity as well as their effectiveness. An attempt will then be made to draw from the historical chronicle a series of policies, renamed acording to the theoretical tradition of nonviolent struggle and capable of constituting a specific nonviolent praxis. These forms of resistance will be embedded, and subsumed, in a Gramscian alternative hegemonic paradigm, so as to enhance the discussion around an organic nonviolent strategy of political resistance.

\section{Popular RESistance in PALESTINIAN History}

Palestinian populations have implemented multiple processes of resistance to face the colonial dynamics imposed in the region since the fall of the Ottoman Sultanate $^{2}$. In these struggles, even when the hegemonic narrative focused in the armed struggle, most of the Palestinian subaltern actors used nonviolent strategies to fight dispossession and defend their identity throughout the Ottoman era, the British Mandate season, and the Israeli occupation. This resistance against colonial powers should be understood in the framework of liberation and self-determination

2 There is an extensive literature on the question of Palestine. Relevant contributions to Palestinian history were made by Pappe (2014), Krämer (2008), Kayyali (2014), Basallote et al. (2017), and Masalha (2018). Knowledge of Palestinian nationalism benefited from research on significant elements like identity (Khalidi, 1997 ) or the struggle for self-determination (Sayigh, 1997). The analysis of women's contribution (Gijón Mendigutia, 2015) and the role of Palestinians living in Israel (Barreñada Bajo, 2006) are key to understand the resistance of the Palestinian national movement. 
fights as a struggle toward social justice in the global context (Said, 1992, pp. 142-145). A rightful struggle according to the United Nations General Assembly, which stressed "the legitimacy of the people's struggle for liberation from colonial and foreign domination and alien subjugation by all available means" (A/RES/3246, XxIx of 29 November 1974).

Palestinian struggle has benefited from nonviolent resistance in different ways throughout recent history, and still does. However, popular resistance does not present a unique front due to the complexity and the colonial fragmentation of the Palestinian society. Palestinians in the West Bank, the Gaza Strip, East Jerusalem, Israel, and in diaspora have developed many different processes of nonviolent struggle (Checa Hidalgo, 2016). The struggle against the wall in Bil'in, the Great March of Return in Khuza' a, the resistance against settler squatting in Silwan, or the Boycott, Divestments, and Sanctions campaign in Spain, look very different from one another, but all are shaped by popular resistance. However, in order to understand the significance and the limitations of popular resistance in Palestinian history, we are going to focus on three fundamental episodes, following Mazin Qumsiyeh (2001): the 1936 Revolution, the 1987 uprising, and the 2000 Second Intifada (or al-Aqsa Intifada).

\section{The 1936-39 Arab Revolt}

The harsh economic and social conditions faced by the Arab Palestinians in the 1930s, as well as the growing proportion of Zionist immigrants to Palestine, were the primary causes of the first of such rebellions. By that time, many forms of struggle, including symbolic and media resistance, had been put into practice: a conscious counter-narrative was already opposing the British attempt to diminish or silence the Palestinian predicament.

The rise of political consciousness in this historical period is manifest in the birth of the Independence Party (1932) and its demand for a Palestine liberated from the colonial mandate. Although they fell into many ambiguities, the Palestinian leaders tried to support the population and promoted forms of resistance such as non-cooperation with the Jews in the maintenance of their factories and farms, and 
defence of the land, for which they forbade the sale of Arab land to individuals and agencies related to Zionist enterprises, eager to swallow up land from poor Palestinian farmers and ambitious landowners (Kramer, 2008).

This boycott campaign was led by the Independence Party in coordination with the Arab Executive Committee. Non-cooperation involved the political, economic, and cultural fields, and included refusing to pay taxes as well as disrupting the welcoming of foreign leaders on their visits to Palestine. A huge number of Palestinians participated in demonstrations, protests, marches, boycotts, strikes, and civil disobedience. The collective movement spread throughout the Palestinian cities and at the political level it was given reality with the birth of the Arab National Committee (Nablus, April 1936) and the Arab Higher Committee led by the Mufti of Jerusalem Amin al-Husseini. Backed by most Palestinian cities, the series of strikes organised by the Palestinian National Movement lasted for six months and was so comprehensive as to be capable of including farms, factories, transportation, and commerce, as well as young people, students, and municipalities (Porath, 1995). The main problem of the 1936 uprising arose when the political leadership dominated by Amin al-Husseini decided to give the revolution another direction by seeking a compromise with the British mandate administration. Amin al-Husseini had led the Arab Higher Committee during a sensitive and complicated time marked by political heterogeneity within the Committee and the difficulties of managing resistance on the field against British repression. Nevertheless, the resistance movement was able to gather enough political capital to draw the attention of several Arab leaders to the miseries and hardships confronted by local Palestinian citizens. During the sixmonth strike, boycott directives were respected, meetings were held, and committees were formed all over Palestine. Aid, service, and medical organisations flourished and supported the material, physical, and psychological needs of the collective effort, especially those of its most fragile members all over Palestine, particularly in marginalised areas (Yousef, 1974). Remarkably, as Ilan Pappe has underlined, throughout the Mandate period there were many occasions in which movements, through the convergence of both Palestinian and Jewish subaltern classes, acted outside the boundaries of the national élites, who were perceived (and often acted) as directing the confrontation according to principles of self-interest. In 1920, Haifa hosted the first Arab-Jewish trade union. Another case is that of 1931, when the 
Histadrut, the Jewish trade union, supported the truck-drivers' strike opposing the rise in taxes. This spirit of collaboration remained alive and progressively involved not only the factory workers and peasants but also small private entrepreneurs and clerks, while governments in London and in the Arab capitals prepared for war. The last example of collaboration belongs to 1947. Eighteen months before the conflict began, the Histadrut and the Arab Workers Union unified the state clerical workers for two weeks in a successful strike that completely blocked official activities (Pappe, 2014). Although, what with the following decades of confrontation, hatred and suspicion became entrenched between the Palestinian and Israeli communities, the above-mentioned episodes are reminders of possibilities existing outside the traditional channels imposed by the political élites, a circumscribed - though not negligible - space for a transnational model of resistance.

\section{The First Intifada}

During the First Intifada, which started in December 1987, the Palestinians made ingenious use of different tools for popular resistance. Collective prayers in mosques, churches, and areas threatened by confiscation and displacement were tremendously effective at the level of boosting the national spirit, expressing the rejection of the Israeli oppressive policies, and winning over international public opinion. The Intifada leadership also revived national, religious, and commemorative events like the "Land Day", the "Nakba", the "Naksa", the "Balfour Declaration", "Martyr's and Captive Day", and the anniversary of the burning of the al-Aqsa mosque in 1969 (Nazzal 2010). The Palestinian population downplayed the Israeli civil administration, tax authorities, security services, and the health and education systems (Qtait et al., 2006).

The widespread boycott, aiming at prolonging and deepening the crisis, involved also private traders, businessmen, artisans, professionals, students, and academic institutions. Although the PLo leadership, exiled in Tunis after the Beirut debacle of 1982, was initially caught by surprise, once it took control of the revolt it worked together with the population, preserving what immediately seemed a fertile state of conflict and daily confrontation (Sayigh, 1997). Active resistance became an 
informal institution capable of reaching all strata of the population, enhanced by a synergy of nationalist ideology and peaceful means (Aliqtisadi, 1989). Stonethrowing became the symbolic activity of the unbalanced confrontation with the Israeli military might, while strikes organised by the popular committees represented the most visible expressions of a process of mass self-teaching.

The Beit Sahour model of non-payment of taxes, which began on July 7, 1988, was one of the finest models of civil disobedience in the modern history of Palestine. All the city's population was united in the boycott and sustained the harsh reaction of the occupation forces, which searched and devastated houses, markets, and shops, confiscated cars, and arrested dozens of men and women. The Palestinians experienced how fruitful it could be, at the psychological and political levels, not to succumb to the lethal force practised by the Israeli army and settlers. Non-compliance was manifested by breaking curfew orders or by forming night-guard committees in neighbourhoods, villages, and rural areas. Orders regarding the closure of educational institutions were ignored or bypassed by creating alternative, voluntary environments for lower and higher education (Erekat, 1990). The combination of field activities and constant intellectual inquiry flourished in ideas concerning the betterment of the Palestinian economy. New agricultural projects were elaborated, and the struggle against the Israeli settlements was enhanced by supporting the wages of rural women and helping labourers to work in Palestinian, rather than Israeli, farms and factories. On many occasions, these activities were the continuation of a policy that had been put into practice since the second half of the 1970s, when, in order to rebuild trust among the population, leftist parties such as the Popular Front for the Liberation of Palestine (PFLP), the Democratic Front for the Liberation of Palestine (DFLP), and the Palestinian Communist Party (PCP), developed independent relief committees in the health and agricultural sectors (Robinson, 1993).

The Intifada also supported unions of writers, artists, students, and industrial and agricultural labourers, and developed a strong media plan to challenge powerful Israeli propaganda. The breadth of popular participation spanned from intellectuals to non-governmental organisations, from trade unions to mayors of cities; all were agents whose capillary action reached throughout the Palestinian territories in support of the most vulnerable elements of the resisting society. The national 
uprising against colonial occupation turned into an opportunity for class solidarity. NGO activities included health relief services, mobile clinics, universities and centres of popular education, agricultural lending committees, and industrial cooperatives, as well as development programs for favouring, through training and financing, women's access to labour. The NGOS also supported trade-unionism, education, and youth movements (Abdel Jawad, 1990).

The greatest impact of such a trend was achieving, to some extent, self-sufficiency and independence from the Israeli economy, changing the culture of consumption and ameliorating agricultural production. Drawing from Abed, it is possible to summarise the goals achieved by the First Intifada in several points (Abed, 1989):

- Developing alternative institutions to those of the occupation;

- Creating a solid nonviolent conscience and strategy, setting as a goal the birth of an independent Palestinian state;

- Splitting Israeli public opinion and building a supportive front for the Palestinians among Israeli public opinion, especially the peace movements and leftist groups;

- Weakening the morale of the Israeli army and lessening the degree of oppression, as excessive lethal force was neutralised by nonviolent strategies and resistance;

- Weakening American support for Israel;

- Prompting international public opinion to support the Palestinians and pushing the agenda for political settlement.

Although the First Intifada turned into a partially armed uprising in the last part of its course, its first two years (1988-1990) constituted an important achievement 
in terms of economic self-empowerment, building economic infrastructures and self-reliance, abandoning the previous improvised schemes of protest, and developing a knowledge of nonviolent resistance methods through collective learning. Moreover, the First Intifada contributed to the transformation of world public opinion, turning in favour of Palestine both international institutions and a constellation of activist groups. At the same time, it showed the cruelty of the occupation and its eagerness in suppressing peaceful demonstrations, besieging cities and towns, and using violence against unarmed civilians through arrests, crippling, and killings (Rigby, 1991).

\section{Popular Resistance in the Al-Aqsa Intifada}

The Second Intifada differed greatly from the first one as violence and military tactics were its main features. Knives, firearms, and "suicide bombing" operations were adopted (Gupta \& Mundra, 2005), and Israeli soldiers and settlers were killed or kidnapped. This means that on a strategic level the main stage of the insurrection was occupied by the military wings of the various factions, while civilians stayed on the background and played a role confined to moral and logistical support. The armed factions were partially detached from the political leadership and acted against soldiers and civilians alike, often inside Israel, without agenda or strategy. In many occasions this proved to be politically fruitless (Andoni, 2001).

However, most of the Palestinian society did not take up arms and some people engaged in nonviolent resistance (Norman, 2010; Checa Hidalgo, 2016). The best example to illustrate this involvement was the struggle against the wall. Israel started the construction of the "West Bank Barrier" in the spring of 2002, based in the idea of preventing attacks from that territory, but it immediately turned out to have political as well as security implications. The wall wrapped around the West Bank population from north to south, confiscating thousands of hectares of Palestinian land and hence putting tens of Palestinian towns and villages under compulsory siege. In 2004 the construction of the wall underwent the scrutiny of both the Israeli Supreme Court and the International Court of Justice. The ensuing trials pushed the Palestinians to seek moral backing both in Israel and abroad in denouncing the wall's illegitimacy as organic with the Zionist colonial project. 
These attempts brought about several success stories. In its advisory opinion, the International Court of Justice, on July 9, 2004, ruled that the construction of the barrier inside Palestine, including Eastern Jerusalem, was contrary to international law. Israel was called to dismantle those sections of the wall protruding in Palestine, de facto defining the barrier as a land-grab operation. The Israeli juridical system answered by demanding the dismemberment of those sections of the wall which had snatched 5110 hectares from the villages of Flamya and Qalqiliya (Jayyous section). In another judgement issued by the office of an Israeli prosecutor, more than 1600 hectares of Palestinian land were restored in the area of Maali Adumim (East Jerusalem). The last of these judicial achievements arrived in September 2007, when the Israeli Supreme Court imposed the reshaping of the wall in Bil'in, giving back to the municipality more than 450 stolen hectares (Ibhais \& Ayed, 2013). In part, Palestinians resorted to known nonviolent forms of popular resistance such as demonstrations, sit-ins, marches, and protests against the new wall and the old roadblocks (Darweish \& Rigby, 2015).

Through the powerful iconic message delivered by the wall, the Palestinian resistance was able to gather significant international support. Solidarity also came from many Israeli groups opposed to the apartheid policies. In many towns, Friday demonstrations set the rhythm of the nonviolent struggle. Thousands gathered from north to south in Bil'in, Aneen, Tayba, Der al-Ghosoun, Kofor Qadoum, Jayyous, Flamya, Habla, Azzun, Qalqiliya, Ni'lin, Budrus, Alma'srah, Um Salamuna, Walaja, Beit Ummar, and Yatta. Every one of these centres established a specific, though somehow convergent, resistance model. Intellectual, artistic, and even athletic activities were staged and followed by media coverage (Dudouet, 2009), although, as the journalist Samer Khwaireh from Nablus remarked:

The media coverage of the popular resistance activities proved the diminished number and size of the events. In the past, resistance offered more collective moments and occasions to confront the occupation. Today you can count the events on one hand's fingers due to many reasons, but mainly lack of public involvement. 
Bil'in proved to be one of the few places where popular resistance became institutionalised. This was confirmed by Abdullah Abu Rahma, coordinator of the popular campaign against the wall in Bil'in: "We cleaned all the village's lands, young people met and formed popular committees that include all factions and institutions, even attracting people from other villages. We began to organise marches and demonstrations on daily and weekly basis" (Ibhais \& Ayed, 2013, p. 26).

In Bil'in creative methods of protest and confrontation against the Israeli soldiers and settlers were utilised. Duties in the popular resistance movement were divided into the media, field, and guard compartments. As further stressed by Rahma, all efforts focused on elaborating innovative measures to draw attention to the land stolen by the wall. In effective theatrical fashion, gallows were tied on trees and candlelight marches were organised, as well as concerts, sport events, and even characteristic wedding ceremonies (Ibhais \& Ayed, 2013). We can summarise the contribution given by the Second Intifada to nonviolent practice as follows:

- Connecting the Palestinian protesters and the international solidarity groups through strings of long human chains, then confronting the Israeli forces, which found difficulty in controlling these large gatherings;

- Boycotting and burning Israeli products according to a devised strategy and then discussing national economic alternatives;

- Honouring all victims, detainees, and wounded in public celebrations;

- Demonstrations and protests brought to the streets new theatrical ways of delivering the resistance message;

- Inviting elements within the Knesset, the leftist Israeli parties, and the Arab Palestinian Legislative Council to participate in popular resistance and express their support in the struggle for freedom; 
- New nonviolent strategies in facing the military forces were adopted, with the outcome that exposition to beating and injuries diminished;

- Women and children took an active part in the demonstrations, increasing the number of participants and engaging categories previously marginal to the resistance movement;

- Israeli law was addressed with the aim of contrasting from "within" the wall and the colonial expansion of the settlements.

These three episodes illustrate how Palestinian struggle benefited from nonviolent resistance. It can be asserted that the Oslo Agreements were possible only thanks to the success obtained by the First Intifada, whose civil rebellion created unmanageable difficulties for the Israeli apartheid system, and for the first time exposed it in its thorough brutality. The poor implementation of the Agreements created the premises for the Second Intifada, during which, although military operation prevailed, there were many important nonviolent expressions of resistance. In the next section, the empirical manifestations of this resistance will be summarised and renamed following the tradition of non-violent strategy, and, in an attempt to offer a wider theorisation and an organic praxis, articulated according to a Gramscian alternative hegemonic paradigm.

\section{THEORY AND PRACTICE OF NONVIOLENT STRUGGLE}

The expressions popular resistance, civilian resistance, and nonviolent resistance overlap in content, from both a theoretical and a practical approach. Differences in their application are conditioned by the social, economic, and cultural variables present in the political context where resistance coagulates. First among such varying elements is the nature of the opponent. Revolution may be the answer to a dictatorial regime, an external enemy, an occupier, or a colonial enterprise. The paradigm of resistance may acquire violent or nonviolent features. These are determined by the previous experience of liberation movements in recent history, the means available, 
and the choices of participants to succeed in a structural change. The act of embracing a model must adhere to the specific socio-political context and answer to the tangible opportunities existing on the ground under the dome of oppression. Different praxes do not alienate the various liberation movements struggling on the international stage, but rather denote them as heterogeneous expressions of a common yearning. The popular response given throughout the years to the Israeli occupation system places Palestine at the core of such an international movement.

There are two eminent schools of thought that have shaped the successful nonviolent resistance experiences at the global level (Vinthagen, 2015). The first is the Mahatma Gandhi school, born out of Indian resistance against the British coloniser at the end of nineteenth century and implemented in the first half of the twentieth century. Gandhian popular mobilisation appealed to the humanity of the oppressor and tried to bring to the surface the enemy's moral nature by means of rational dialogue and the proposal of a shared path towards justice, intended as indistinguishable from truth (Madeyah, 2002). The second school gravitates around the theories of Gene Sharp, more focused on a rational/pragmatic strategy aimed at defeating the opponent and less concerned with the exploration of the latter's humanity and the attempt to stimulate his good nature (Sharp, 1980).

It is important to underline how the approach enacted by most popular and peaceful resistance movements is founded on a vision capable of identifying the ganglions of the enemy's dominion, especially the material and cultural elements capable of bringing the subject population to a state of submission and cooperation that are quintessential in preserving the status quo. Oppressor and oppressed live in a perverted and unequal symbiosis that strengthens the former and obliterates the latter. Studies on totalitarian/authoritarian political regimes have focused on the importance of endeavouring to disrupt the structures that allow these regimes to function so subtly and effectively (Ackerman, 1994). Sabotage must concentrate on the military, economic, political, diplomatic, and cultural ganglions favouring coercion and passivity. The local, regional and international levels of the struggle must be addressed. A long-term rational strategy considering causes and effects has to be devised in order to achieve tangible results. 
One of the pillars of popular resistance, common to all nonviolent movements, is the effort to increase the cost of the occupier's repressive policies and consequently reduce the use of brutal force and deadly weapons (Galtung, 1989). Another constitutive goal is that of eroding the opponent's legitimacy among its local and global allies. This would determine a reduction of the economic and military support it enjoys and a possible division among the political constituency and the military ranks, between the instigators and the executors of the oppression (Semelin, 1993). With even wider strategic thoroughness, resistance against a foreign occupier must address all levels of political reality while enhancing the certainty among the general public that the people's will is stronger than the occupier's daily physical and psychological pressures. As we have already remarked, the nature of the confrontation depends on the political context and its protagonists. Following Werner Rings (1982), and Darweish and Rigby (2015), it is possible to identify five forms of nonviolent resistance:

- Symbolic Resistance: actions to allow resistance groups coalesce and adopt the same symbols, language, signs, and even clothes, which are capable of promoting national feeling among the people. Resistance groups attend national events and folklore revivals;

- Polemic Resistance: actions to oppose the occupying power voicing protest and trying to persuade others of the need to fight on;

- Offensive Resistance: actions aimed at frustrating the opponent, such as demonstrations, strikes, and other dynamic activities;

- Defensive Resistance: actions to aid and protect those in danger, thereby preserving human lives and human values endangered by the oppressor;

- Constructive Resistance: actions to challenge the existing imposed order by seeking to create alternative institutions that embody the values that the resistance groups defend. 
In order to create a civil popular resistance capable of dismantling a state of submission, be it occupation, colonisation, or a totalitarian regime, it is necessary to acknowledge the favourable conditions starting from which a cohesive spirit could emerge and act:

- A strong sense of identity and belonging to the community and the thick fabric of solidarity necessary to resist repression can exist only if class differences are reduced or abolished. Democratic culture is the primary sphere of integration;

- Freedom, human rights, intellectual, and religious tolerance are the only means to grant the resistance body a wide and solid participation in a community base;

- All grassroots institutions must be mobilised: civil society organisations, popular committees, local councils, trade unions, youth and student associations. They can all participate in forging the alliance that would be able to confront the opponent at the cultural and intellectual levels;

- Patience must be at work for the feeling of solidarity to attract the attention and support of other nations, allowing no discrimination at the social, economic, or political levels (Roberts \& Garton Ash, 2009);

- Self-confidence and creativity are paramount at both the individual and collective levels. New abilities and goals must be constantly created and trust in the possibility of victory built through progressive achievements. Parallel to this, the strategy and organisation of the opponent would have to fall under incessant scrutiny;

- Experienced field leaders must work to strengthen the organisational structure and the protest movement, and channel all the devised collective activities to have nonviolent outcomes;

- It is paramount to devise a clear oppositional strategy articulated by pivotal tactics and, through it, to shape the activists' work on the field. The resistance drive among groups must be constantly enhanced, not only by keeping 
high and alive the will to struggle, but also by training the field activists on how to avoid being dragged into the enemy's provocations and attempts to empty and frustrate the popular resistance. Constant dialogue must be maintained among each group's members and among the groups themselves. In this way the message can reach the peripheral strata of the population and, moreover, address the fragile constituencies within the opponent's civil sphere, encouraging some of its security and bureaucratic elements to join the resistance movement and promote its political discourse;

- Popular resistance must become a gravitational centre capable of attracting backing for its peaceful revolution at all levels, local and international. The number of active participants coincides with an increase in economic, media, medical, and logistical support (McAdam, 2009).

What has been condensed above is necessarily an imperfect summary inductively drawn from the Palestinian history of nonviolent resistance. The porous categories describing the forms of defiance, as well as the conditions required for their fruitful implementation, represent a multitude of episodes and methods which, although capable of yielding numerous successes, have failed along the years to become an organic, shared paradigm of resistance. It is for this reason that we will now try to amalgamate the Palestinian resistance grammar in a Gramscian discourse, believing that the outcome could result in a clearer perspective on the necessity to articulate a structured nonviolent strategy out of the endless episodes. In order to proceed it is necessary to explain briefly some of the Gramscian concepts that we will be using in our attempt.

\section{Palestinian nonviolent Resistance Within a gramscian PARADIGM}

In re-evaluating the predominant role occupied by the concept of structure in Marxist theory, Gramsci renovated the theories concerning power, pointing to political and cultural elements as essential means through which a dominant class rules over the vast majority of the subalterns. While dominion indicates the economic and coercive 
realms, hegemony describes a condition in which the subordinates are subject through public and private apparatuses (the educational and media systems, cultural and political organisations, organic intellectuals-all private bodies adhering voluntarily to the hegemony) to a type of cultural pressure that turns their subservient state into an accepted tradition, a common sense notion internalised by the masses and used for the economic-corporative interests of the dominant class. According to Cospito:

Hegemony, in the "strong" sense in which Gramsci uses it in a series of notes in the Notebooks, with explicit reference to Lenin's use of the term (Q4, 38), which in its turn represents the translation, in changed historicopolitical conditions, of Marx's doctrine of the permanent revolution (Q8, 52), is synonymous with political leadership [direzione politica], sometimes united with, sometimes opposed to dominion, coercion (Q1, 44) or, in an even more pregnant sense, an element of the connection between the moment of consent and that of force (civil or political hegemony connected and not contraposed to the cultural or intellectual one). (Cospito in Frosini \& Liguori, 2004, p. 89)

The category of hegemony is intimately linked with that of the Integral State. According to Gramsci, the state hegemonic apparatuses in the modern democracies started to widen after 1870, during the European colonial expansion (Frosini \& Liguori, 2004). The state, a solid expression, actually, a tool of the bourgeois class (the structure will always be a constitutive concept for Gramsci-sometimes misunderstood as just a theorist of the superstructure), would from this moment develop from a minimal, coercive night-watchman/veilleur de nuit ("gendarme-state" or "corporative state" for Gramsci) into a complex organic device using violence and consensus, that is hegemony, to organise an increasingly homogeneous society. In Gramsci's own words, the "general notion of state" includes "elements which must be restored to the notion of civil society (in the sense, one might say, that state = political society + civil society, that is hegemony protected by the armor of coercion)" (Gramsci, 2007, Q6 88, pp. 763-764).

In Gramsci the notion of hegemony is inextricably tied to that of historical bloc, the (bourgeois) class concretion where the intertwining of structure and superstructure, 
of dominant social relations of production and their supportive ideologies, have agglutinated a heterogeneity of interests and identities into a ruling alliance (Gramsci, 2007, Q7 21; Q8, p. 182). What has to be done, then, to replace the hegemony of the historical bloc with the hegemony of the subaltern classes? Drawing from military parlance, Gramsci differentiates between two possible strategies: the war of manoeuvre and the war of position (Gramsci, 2007, Q7, p. 10). The war of manoeuvre can be assimilated to a frontal assault on the ruling hegemony, a permanent revolution aimed at conquering the state's institutions when the grip of the historical bloc is loose and hegemony particularly fragile or reduced to dominion. An example quoted by Gramsci is the October revolution in Russia. The war of position, on the contrary, is waged against a solid hegemony and consists in a progressive conquest of "trenches", the ganglions — structural as well as superstructural- where the hegemony organises and thrives. "In politics, the siege is reciprocal" (Gramsci, 2007, Q6 138, p. 802), states the Sardinian philosopher. This implies that the loci of contention are identical for both the hegemonic and subaltern fronts, and that both the war of manoeuvre and the war of position are articulated according to the specific historical contingency, although only the latter, "once won, is definitively decisive".

In order to describe the process through which revolutionary change can be defused, Gramsci adopted — inheriting it from Cuoco and Quinet - the concept of passive revolution. Although the term bears stratified connotations in the Prison Notebook, from political warning to interpretative approach, from political program of the moderate parties in the Italian Risorgimento to near-synonym for the war of position (Frosini \& Liguori, 2004), its open semantic generally frames the dynamic of conservative restoration, of which Fascist Caesarism is one form, relying on a charismatic figure. The other is Transformism, a sedimented, traditional practice in the young Italian tradition and in the twentieth-century bourgeois Europe by which the hegemonic bloc co-opts the leadership of the subaltern groups, thus neutralising their revolutionary drive.

Let us now turn our attention to the correlation existing between Gramsci's concepts and the Palestinian case. We do not believe, as Leech does, that Palestine is fully embeddable in a hegemonic discourse (Leech, 2016). Or, rather, as we will explain further on, the concept of Israeli hegemony has to be subsumed to an 
international level. Leech pinpoints, in the period going from the First Intifada to the more recent state-building, following the collapse of the Oslo Process, the season during which a hegemonic, transnational Israeli-Palestinian bloc was formed. Indeed, we have to look a long way backwards in order to grasp the real nature of the deep Palestinian socio-political structures, and their being affected by a failed hegemony (Foschi, 2018). From its birth, the Ottoman Empire relied on a heavily decentralised pattern to maintain control over its endless territories. Administrative decentralisation coincided with an accumulation process that, by the eighteenth century, had crystallised in provincial oligarchies that not only ruled unrestrained over the territory, but often displayed rebellious stances toward the central authority of Istanbul. The Tanzimat reforms of the second half of nineteenth century according to Gramsci the season during which the Western bourgeois states turned form "night-watchman" to hegemonic, integral states (Gramsci, 2007, Q6, p. 88) were only capable of slowing down the potentates' political and economic autonomy. In the same period the region was entering into the capitalist market and more organically into the global élitist constellation that has existed since the sixteenth century, which Peter Gran has named the Rise of the Rich (Gran, 2009).

When after World War I and the Hashemite betrayal of the national project, Great Britain and France partitioned the Arab provinces of the defeated Ottoman Empire in zones of influence, the new states created and ruled by the mandatory powers inherited the provincial historical blocs that had been expanding their dominion for centuries. In Iraq, Syria, Lebanon, Jordan, and Palestine, however, dominion was never subsumed into hegemony, and vast portions of the population were left at the margins of the weak states born out of the Sykes-Picot imperialist plan.

In Palestine the demiurgic reorganisation was further disrupted by the Balfour declaration of 1917, which granted the Zionist colonial movement a national home. During the mandate, the Palestinian élite collaborated awkwardly with the British rule to preserve their privileges, a situation that continued after the 1948 defeat, when thousands of individuals constituting or gravitating around the historical bloc fled Palestine, now divided between Egyptian and Jordanian control. Under the oppressive tutelage of the two states, the depleted economic structures could not trigger a process of social stratification, while every attempt at local institutional 
genesis was thwarted or put under control in Cairo and Amman. By 1954 the disruption of the economy, shattered in its internal balance and having to deal with a new internal geography and the reformulation of the destinations of its exports, made 50 percent of the Palestinians fully unemployed, while a further 20 percent suffered from seasonal unemployment (Mansour, 1988).When, with the "Six-Day War" of June 1967, Israel occupied the West Bank, Gaza and the Sinai Peninsula, Palestine fell under a scheme of political economy that Minister of Interior Moshe Dayan had defined as an "open door" policy, "a rapid pacification of the territories occupied by Israel, whose labour market would open up to this new supply of cheap workers" (Filiu, 2014, p. 126). In fact, this was nothing but a colonial exploitation, a planned fragmentation of the growth serving the ruling economy to the detriment of the subaltern one, something that Sara Roy has labelled "de-development", "a process which undermines or weakens the ability of an economy to grow and expand by preventing it from accessing and utilizing critical inputs needed to promote internal growth beyond a specific structural level" (Roy, 1987, p. 56). By this time the Palestinian élite, bound to Jordan by economic interests and pressured both by Israel and the PLO, had circumscribed its activity to the municipal administration, which acquired political relevance as the only remaining administrative unit left to Palestinians after Israel had suspended the districts (muhafatha) existing under Jordanian rule. Israel, willing to maintain peace and control over the occupied territories, let the West Bank élite coordinate the minimal municipal activities and express its opposition feelings as long as this did not mean any structural agglutination of policies and institutions at a national level. Jordan intended to keep the role of major negotiator with Tel Aviv, and while initially opposing the élite's collaboration with Israel, it then softened its position when the compromise defused the notables' nationalism, already constrained in its incidence on the economic ties with Amman (Mishal, 1981).

Meanwhile the Palestinian resistance had emerged and flourished. Since the mid-1960s, with varying strategies, the armed organisations forming the Palestinian Liberation Organisation (PLO), Fatah, the Popular Front for the Liberation of Palestine (PFLP), the Democratic Front for the Liberation of Palestine (DFLP), and the Palestine Communist Party (PCP) had waged a war of national liberation. Fatah, the main shareholder and recipient of the political and financial support coming from 
the Soviet Union and the other Communist countries around the world, had led the PLO to become a real parallel state, a military and bureaucratic archipelago dwelling in the refugee camps of Jordan, Lebanon, and Syria that after a while developed into a neopatrimonial system tainted by patronage and corruption (Yezid, 2004). It was the PLO's dispersion and collapse after the 1982 Israeli siege of West Beirut that would, along with the intolerable economic and social condition, push the West Bank and Gaza to trigger the First Intifada. It is however an interpretative stretch to assume that the Intifada "proved that the PLO could not exercise a monopoly over political activism within the Palestinian population" and that the Oslo peace process was merely "the product of the elite interest and no genuine consensual relationship was developed between those elites and the general population on either side" (Leech, 2016, pp. 169-170), that is, the Palestinian and the Israeli. Even from Tunis the PLO had been able to take over, or hijack, the spontaneous Intifada insurrection. This represented an unmissable occasion for a greatly enfeebled para-state, dispersed and internally divided. Furthermore, the collapse of the Soviet Union and disgraceful support granted by Arafat to Saddam Hussein during the first Iraqi War (19901991) had left the Palestinian cause internationally isolated. The clearest sign of the PLO and Fatah decline was the birth, in 1982 and 1987, of two religious parties, Islamic Jihad and Hamas, which reacted to what appeared to be the end of an entire resistance era, embodied by the Arab countries, Nasserist pan-Arabism, and the secular and leftist movements. Religion began to fill the void created by a long season of failures. The Oslo agreements were welcomed with overwhelming jubilations and support in the Occupied Territories and, as a proof of their effect on the Palestinian constituency, they caused a considerable reabsorption of what during the Intifada appeared as an inexorable growth of the armed religious movements.

Only the disastrous implementation of the Oslo peace process and, indeed, the Israeli-Palestinian élite convergence again fragmented the Palestinian population. It is unquestionable that, after the collapse of the Soviet Union, the United States considered the Oslo process as a moment of the wider plan to reconfigure the Middle East, opening it to the unrestrained flux of transnational capital. In the midst of this umpteenth demiurgic manipulation, a very limited group of Palestinian firms, based in the Gulf and thriving in wealth and influence since the 1948 and 1967 diasporas, penetrated what remained of a dismembered Palestinian economy and soon became, 
through its various declensions on the territory, dominant in setting its economic paradigm (Hanieh, 2010). Likewise, on a strictly political level, the us-Israel alliance successfully made consistent efforts to determine the "right partners", that is to say, individuals and parties considered to be suitable for the peace process (Turner, 2001). This, however, did not imply the formation of a hegemonic bloc. It was rather a re-edition in a new context of what had taken place under British, Egyptian, Jordanian, and Israeli occupation: an ambiguous, elitist collusion of the occupied with the colonial occupier feeding the popular disappointment, triggering the Second Intifada, the striking Hamas victory in the 2006 elections and, eventually, the 2007 Hamas-Fatah war in Gaza, the latest epitome of the impossibility to create a state (by no means integral) and, clearly, to modulate a hegemony. Drawing again from the Gramsci vocabulary we might define the Oslo process a derailed peaceprocess turned into a failed passive revolution. This does not mean that the Gramscian workshop cannot be utilised to understand the Palestinian resistance strategies.

The persistence of the old elitist/colluded bloc within the Palestinian constituency certainly constitutes an impediment in constructing a solid front against the Zionist encroachment, and although its gravitational force continues to attract, through the benefits of collaboration, new affiliates among the middle classes, it is far from having conquered a considerable portion of the popular consensus. Even Fatah, dominant in the Palestinian Authority, is internally divided and shows feelings of discontent towards the policies adopted by the party and the PA with Israel. It is sufficient to leave East Jerusalem and Ramallah and submerge into the Palestinian periphery to perceive the not-too-silent mass ready to be radically engaged in a democratic struggle for liberation. This was visible during the resistance processes developed along the Great March of Return in the Gaza strip (Abusalim, 2018). Popular consensus is also forming around a common political project. Here, the creation of a Palestinian state next to Israel, as defended by the PA and the core of the Palestinian national movement, is being increasingly challenged by the one state solution: a shared state were Israelis and Palestinians would live with equal rights and freedoms (Tilley, 2005; Hussein, 215).

Nonviolent praxis has to address both internal and external hegemonies, of which Israel constitutes the osmotic chamber. If, following Morton (Morton, 2007) and 
the above-mentioned Gran, we assume that the category of hegemony can and has to be applied to the international relations system, be it the constellation of states or of élites, and that the United States have been and still are the heart of such global supremacy, then what the Palestinians are facing is much more than a brutal apartheid or a "national" hegemony. There hardly exists a better example of diplomatic, economic, media, and military support provided by one state to another than that flowing from the United States to Israel (Chomsky, 2009). When implemented, therefore, resistance is always, even if indirectly and varying in its incidence, three-pronged and active on a national level, against the collaborationist bloc of the PA, in Tel Aviv against the Zionist government, and in Washington, the global hegemonic ganglion and guarantor of Israel's colonial policies. In such a perspective the nonviolent war of position is of fundamental relevance.

As demonstrated by this brief historical summary, since the 1936 rebellion, the Palestinians have relied heavily on all those activities aimed at preserving and enhancing their national identity. Religious ceremonies, folklore festivals and historical commemorations served not only the idea of agglutinating a community fragmented by diasporas, poverty, and occupations, but also of replying to an Israeli forethought, notoriously summarised by Prime Minister Golda Meir, "there is no such a thing as Palestine in history, absolutely not”. As Gramsci famously noted, "the history of subaltern social groups is necessarily fragmented and episodic [...] subaltern groups are always subject to the activity of ruling groups, even when they rebel and rise up" (Gramsci, 2007, Q25 2, p. 2283). Cultural academic studies, both in Palestine and abroad (and especially in the English language), continue to contribute in solidifying the Palestinians' endangered identity, and their rights as a national community. The "popular culture" approach, a slow, though relentless, agglutination and solidification of the subaltern Palestinian identity, is a fundamental stage in the war of position countering the hegemonic narrative. The alternative discourse can pass through cinema or rap music, and is not only able to affect the political process, but also plays a role of crucial importance in processes of class formation and class consolidation (as in the growth and expression of middle-class Palestinian taste), and as a tool both to fortify nationalist ideologies and hatreds and to undercut the hegemony of secular-nationalist ideology (as in "martyrdom culture"). Finally, this approach is attentive to the ways in which popular culture 
forms necessarily "articulate" with broader social and economic processes and historical moments (Stein \& Swedenburg, 2004).

Oblivion, however, does not only threaten the past and its cultural expressions, it is also the systematic effect of an Israeli media preponderance clouding the daily manifestations of oppression and injustice. As many correspondents in Israel/ Palestine would witness:

It is impossible to work here and report on the Israeli-Palestinian conflict. We receive huge pressures from the agencies and Israel holds our visas, which are under constant threat of decline. The result is that after a while every serious professional asks to be moved elsewhere, and the coverage remains in the hands of the pro-Israeli, or those prone to compromise.

Israeli hostility towards reporters, scholars, and international NGOs has in the last years materialised in menaces of expulsion, denied visas, and discriminatory laws (Reuters, 2017; RT, 2017; Beaumont, 2017). In Italy, when a journalistic report containing something deemed unfavourable to Israel is published, an online publication called Informazione Corretta (Correct Information), which day in and day out punctiliously browses the main newspapers, denounces the contents, and invites its readership to protest by offering the paper's references. In the few publications willing to offer a balanced narrative on the Israeli-Palestinian conflict, pressures filter down the paper's hierarchy, often constraining the journalist's reporting. As everywhere else in the West, a continuous and organic narration is impeded, and Israeli media dominance is preserved. The hegemonic device, nestled in Universities and newsrooms, preserves the cemented international public opinion and impedes any petition of support for the Palestinian cause to emerge in the political discourse. Needless to say, the device is operative in Israel, where with few exceptions - such as a few intellectuals and the newspaper Hareetz - the readership is subject to a unidirectional narrative. The outcome, both at regional and global levels, is the enormous difficulty in eroding the pro-Israeli constituency, and through it creating an oppositional democratic front. As the South African case demonstrates, even if in a different historical context, the combination of predominantly nonviolent and media coverage can activate an international mobilisation, both political and 
economic, both state-led and private-led (Clark, 2011; Rodman, 1994). It is not by chance that even with a limited public space at its disposal, the Boycott Divestment and Sanction (BDS) campaign has created many concerns and not a few difficulties to Israel (MacMahon, 2014).

As Fawzi Ismail, founder of the Amicizia Sardegna Palestina association and President of the Palestinian communities in Europe, states, "it is difficult to change the collective conscience in Europe, historical patron of Israel, part of a continental culture that renovates itself starting from the schools' textbooks and is organic in terms of political and economic interests". When reasoning on the role played in Europe by the Palestinian community, Ismail underlines "reality" as the most important tool in the struggle, the capacity to show what happens daily in the Occupied Territories:

We try to amplify the Palestinian voice, believing in the Europeans' intelligence, in their capability to understand. With a demonstration in Rome, Paris, or Berlin we don't free a prisoner from jail, but we defend the right to exist by disrupting Israel's cultural and media hegemony.

Analysing the development of the resistance strategy, Ismail claims that:

From a European perspective, before the armed struggle of the 1960s-1980s the Palestinians were merely poor refugees in need of health assistance. People living under occupation have the right and the duty to choose the more useful form of struggle, though the highest expression of resistance for the Palestinians has been the First Intifada. Israel could do nothing against strikes, civil disobedience, and children armed with stones, and it became politically isolated. By not choosing the military path the Palestinian cause gathered an enormous moral capital, internationally recognised. Unfortunately, our leadership did not persevere, and with Oslo Israel saved itself from the verge of collapse. After the attacks of September 11, 2001 in New York, Israel was capable to conflate terrorism with the Palestinian struggle. Also, for this reason, the resistance form taken by Second Intifada has been wrong. We still suffer from this skilful perversion of reality: for 
the European media the last mass hunger-strike organised by the detained Palestinians was a protest of criminals. There was no comprehension of the reasons behind it. For this reason, our struggle must be cultural before than political. Only culture can hinder the dystopic version of past and present reality manufactured by Israel. I remember Golda Meir after the death of Ghassan Kanafani, killed by Israeli agents, when she said that he was more dangerous than a soldiers' battalion.

Ismail refers to the 41-day long mass hunger-strike with which in April-May 2017 at least 800 hundred Palestinian prisoners led by Fatah leader Marwan Barghouti protested against life-conditions in the Israeli detention system. The strike was a rare success for the Palestinians and the day before the protest began an open letter from Barghouti was published in the New York Times. Barghouti's article caused outrage in Israel and the Netanyahu government demanded and obtained an immediate apology, which focused on the "criminal" nature of Barghouti (Spayd, 2017). Indeed, the latest in an endless string of about-faces, the umpteenth proof of the efficiency Israel maintains in shaping the media system, and the unopposed hegemonic discourse with which the intrusive intervention is intertwined.

As many others in the Palestinian history of resistance, Kanafani and Barghouti —albeit his role as military commander during the Second Intifada and his present role, even if imprisoned, as a political leader - can be described by what Gramsci defined as organic intellectuals when the national struggle is taken into consideration. Even from different ideological perspectives, they have executed organisational and connective functions within the alternative-hegemonic resistance (Gramsci, 2007, Q12 1, p. 1519). The role of the organic intellectuals is fundamental in devising and modulating the nonviolent struggle, especially because the latter necessitates the widest popular participation. They must work to include in the womb of the national resistance the highest possible number of active participants, for in various degrees "all men are intellectuals" (Gramsci, 2007, Q12 1, p. 1516), and when stirred by a collective revolutionary reason, their function becomes decisive in all the resistance activities we described in the previous paragraph. Strikes, social disobedience, boycotts, new parallel institutions, and cultural activities: all the nonviolent praxes we have summarised under the labels of symbolic, polemical, 
offensive, defensive, and constructive resistance exist in the Palestinian history of rebellion and can once again, in a structured, organic strategy, be adopted to sap the hegemonic solidity both at structural and superstructural levels. Even considering the historical continuity of the nonviolent struggle, and the recent PA's focusing on institutionalisation and sustainable development, what has been achieved so far is quite miserable, given that Palestinians are forced to live in little more than $20 \%$ of the land they possessed before 1948, and this territorial leftover has been colonised by almost 400,000 Israeli settlers (Berger, 2017). Internally, Palestinian society is divided into five different groups (Palestinians in the West Bank, the Gaza Strip, East Jerusalem, Israel, and in diaspora) with different political interest and goals due to the situation created by this colonial fragmentation. Every group enjoys different policies and practices of colonial oppression and they consider different political projects suitable to their particular needs (Checa Hidalgo, 2017). Furthermore, competing parties have fractured the political scenario and are increasingly distant from a passive population.

If this gravitational force spontaneously traps the Palestinian community, an opposite communicative effort must be made to awaken the other passive elements composing the thick hegemonic layers: the Israeli, European, and American multitudes where the necessity to support the Palestinians' rights is still a minority discourse. Israel owes its existence to an intense activity of lobbying both at the League of Nations and at its successor as the global political arena, the UN. Subsequently, when the organism produced resolutions going against Tel Aviv's interests, such as Resolution No. 242 asking for complete withdrawal from the pre-1967 territories, or the more recent appeal to obtain the recognition of Palestine as a member state, Israel shifted to a policy of systematic de-legitimisation of the New York assembly (Gribetz, 2012). Especially after Oslo, the UN and its parallel organisations, the UNESCO (UN Educational, Scientific and Cultural Organisation) in particular but also the ICC (International Criminal Court), have become the theatre of a diplomatic struggle where the cultural perception of the Israel-Palestine conflict becomes central in sanctioning victories or defeats. International legal processes, though emptied by political power and practice, constitute another major stage for resistance and, once again, as Burgis-Kashtala (2014) has stressed, the creation of narratives fundamental for their outcomes. 


\section{Conclusions}

Nonviolent means are embedded in the long history of the Palestinian resistance. Since the 1936 revolt they have been intertwined with the armed struggle, and proved to be of tremendous effectiveness in the First Intifada. Only lately, however, and mainly in a nominal fashion, nonviolence, institutionalisation, and economic development have been adopted as political paradigm by the Palestinian Authority. Their feeble implementation has to be traced back to the deep structure of the Palestinian society, subject throughout its modern history to the dominion of an élite who has colluded with all the occupying forces: the Ottoman Empire, the British Mandate, the Egyptian and Jordanian protectorates, the Israeli Zionist governments and, finally, the Palestinian Authority. The Gramscian approach allows us to clarify the position of Palestine in a hegemonic/ subaltern dialectic and offers a theoretical and practical framework in which the numerous but dispersed nonviolent praxes can be subsumed. The dominion expressed by the Palestinian élite turns into hegemony when we assume that Israel belongs organically to the Western bloc led by the United States, its unfailing patron. Classic nonviolent resistance operates at both structural and superstructural levels in a war of position aimed at conquering the ganglions of civil society. What is required is a long-term, progressive mass struggle capable of agglutinating the fractured constituency and forcing the political establishment to embrace, without ambiguity, the oppositional strategy. Enfeebling Israeli occupation through strikes, boycotts and demonstrations is just the first stage of a struggle holding in its narrative dimension the key to address the international community and challenge its hegemonic discourse, from the "system of trenches" of civil society to the official stages where diplomacy takes place, as the United Nations. In order to achieve this, the Palestinian history and culture as well as the daily string of injustices taking place in the West Bank, or the 10-year long siege of the war-devastated Gaza Strip, perhaps now at its end, should find a "real", constant presence in the academic and media narratives. Culture, injustice and peaceful rebellion should become the heart of a cultural-media strategy of global dimensions, for if hegemony is global, as we believe, so too should be the alternative-hegemonic strategy and the reality of its nonviolent praxis, even if enacted from a forgotten periphery such as Palestine. 


\section{REFERENCES}

Abdel Jawad, S. (1990). Regarding the tasks of Next Stage: Methods of Mass Support to Intifada. Jerusalem: Center for Development Studies. Original in Arabic, داوجل دبع ، حلاص

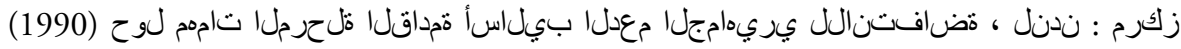

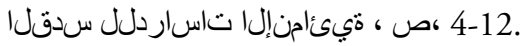

Abed, G. T. (1989). The Political Economy of Resistance in the Occupied Territories. Journal of Refugee Studies, 2(1), 55-63.

Abusalim, J. (2018). The Great March of Return: An organizer's perspective. Journal of Palestine Studies, 47(4), 90-100.

Ackerman, P. \& Kruegler, C. (1994). Strategic non-Violent conflict. The Dynamics of People's Power in the Twentieth Century. Westport: Praeger.

Aliqtisadi, S. (1989). Methods of Popular Resistance in the First Intifada, Samed, 11(75),

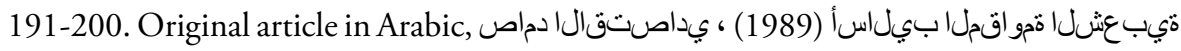

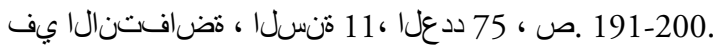

Alnasseri, S. (2016). Arab Revolution and Beyond. The Middle East and Reverberations in the Americas. Basingstoke: Palgrave Macmillan.

Andoni, G. (2001). A Comparative Study of Intifada 1987 and Intifada 2000. In R. Carey (Ed.), The New Intifada: Resisting the Israeli Apartheid. London: Verso.

B'tselem. (2011). 29 June 2011: Separation Barrier moved, but some 1,300 dunams of Bil'in land remain on other side. Retrieved from https://www.btselem.org/topic-page/29611-1300

Barghouti, M. (2017). Why We Are on Hunger Strike in Israel's Prisons, New York Times. Retrieved from https:/www.nytimes.com/2017/04/16/opinion/palestinian-hunger-strike-prisoners-call-for-justice.html

Bartkowski, M. (Ed.) (2013). Recovering nonviolent history. Civil resistance in liberation struggles. London-Boulder: Lynne Rienner Publisher. 
Barreñada Bajo, I. (2006). Identidad nacional y ciudadania en el conflicto israelopalestino: los palestinos con ciudadanía israeli, parte del conflicto y excluidos del proceso de paz. Tesis doctoral, Universidad Complutense.

Basallote Marín, A., Checa Hidalgo, D., López Arias, L. and Ramos Tolosa, J. (2017). Existir es resistir. Pasado y presente de Palestina-Israel. Granada: Comares.

Beaumont, P. (2016). Israel passes law to force NGos to reveal foreign funding. The Guardian. Retrieved from https://www.theguardian.com/world/2016/jul/12/ israel-passes-law-to-force-ngos-to-reveal-foreign-funding

Beaumont, P. (2017). Hamas and Fatah sign deal over control of Gaza Strip. The Guardian. Retrieved from www.theguardian.com/world/2017/oct/12/ hamas-claims-deal-agreed-fatah-control-gaza-strip

Berger, Y. (2017). How Many Settlers Really Live in the West Bank? Haaretz Investigation Reveals. Haaretz. Retrieved from https://www.haaretz.com/israel-news/. premium-1.794730

Berrigan, F. (2009). Made in the U.S.A.: American Military Aid to Israel. Journal of Palestine Studies, 38(3), 6-21.

Botta, A. \& G. Viaggi (2012). A Post-Keynesian Model of the Palestinian Economy: The Economics of an Investment-Constrained Economy. Review of Political Economy, 24(2), 203-26.

Burgis-Kashtala, M. L. (2014). Over-stating Palestine's un Membership Bid? An Ethnographic Study on the Narratives of Statehood. The European Journal of International Law, 25(3), 677-701.

Carter, A. (2012). People power and political change. Key issues and concepts. Milton Park: Routledge.

Checa Hidalgo, D. (2016). Resistiendo la ocupación de los Territorios Palestinos. Oportunidades y desafíos de la lucha no-violenta. Miscelánea de estudios árabes y hebraicos. Sección Arabe-Islám, 65, 3-20. 
Checa Hidalgo, D. (2017). El desarrollo de identidades palestinas diferenciadas bajo el poder colonial. In Ch. Olivieri and A. Ortega Santos (Eds.). Decolonizando Identidades. Pertenencia y Rechazo deldesde el Sur Global (pp. 131-144). Granada: Instituto de Migraciones.

Chomsky, N. (1999). Fateful Triangle. The United States, Israel, and the Palestinians. London: Pluto Press.

Clark, N. L. \& Worger, W. H. (2011). South Africa. The Rise and Fall of Apartheid. London and New York: Routledge.

Darweish, M. \& Rigby, A. (2015). Popular protest in Palestine. The uncertain future of unarmed resistance. London: Pluto Press.

Dudouet, V. (2009). Cross Bordet Non-Violent Advocacy During the Second Intifada: The International Solidarity Movement. In H. Clark (Ed.), Unarmed Resistance and Global Solidarity. London: Pluto Press.

Erakat, S. (1990). Intifada and the Surrounding Variables. Jerusalem: Dar Alawdeh for Studies and Publications. Original in Arabic, تاريغت

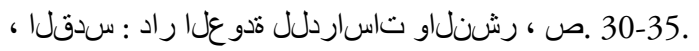

Foschi, L. (2018). Failed Hegemonies and Reactive Intrastates. The Cases of the Patriotic Union of Kurdistan in Iraq, Hezbollah in Lebanon and Hamas in Palestine. PhD thesis, University of Cagliari.

Frosini, F. \& Liguori, G. (eds.) (2004). Le parole di Gramsci. Per un lessico dei Quaderni del Carcere. Roma: Carocci.

Galtung, J. (1989). Non-Violence and Israel/Palestine. Honolulu: University of Hawaii Press.

Gelvin, J. L. (2011). The Modern Middle East. New York and Oxford: Oxford University Press. 
Gijón Mendigutia, M. (2015). Historia del movimiento de mujeres en Palestina, Tafalla: Txalaparta.

Gramsci, A. (2007) [1975]. Quaderni del Carcere (Edizione critica dell'Istituto Gramsci, Valentino Gerratana (Ed.)). Torino: Einaudi.

Gran, P. (2009). The Rise of the Rich-A New View of Modern World History. Syracuse, NY: Syracuse University Press.

Gribetz, J. (2012). The Question of Palestine before the international community, 1924: A Methodological inquiry into the Charge of "Bias". Israel Studies, 17(1), 50-77.

Gupta, D. \& Mundra, K. (2005). Suicide Bombing as a strategic weapon: an empirical investigation of Hamas and Islamic Jihad. Terrorism and Political Violence, 17(4), 573-98.

Hanieh, A. (2010). The Internationalisation of Gulf Capital and Palestinian Class Formation. Capital \& Class, 35(1), 81-106.

Hussein, Ch. (2015). The Re-Emergence of the Single State Solution in Palestine/Israel Countering an Illusion. London: Reutledge.

Ibhais, H. \& Ayed, K. (2013). The Separation Wall in the West Bank. Beirut: Al- Zaytounah Center for Studies and Consultations.

Kayyali, A. W. (2014). Palestina, una historia moderna. Colonización sionista, imperialismo británico y resistencia nativa hasta 1939. Madrid: Bósforo Libros.

Khalidi, R. (1997). Palestinian identity: The construction of modern national consciousness. New York: Columbia University Press.

Kimmerling, B. \& Migdal, J. S. (2003). The Palestinian People. A History. Cambridge, MA: Harvard University Press. 
Kramer, G. (2008). A History of Palestine from the Ottoman Conquest to the Founding of the State of Israel. Princeton: Princeton University Press.

Leech, P. (2016). The State of Palestine: A critical analysis. Milton Park 4: Routledge.

López Martínez, M. (2017). ¿Noviolencia o barbarie? El arte de no dejarse deshumanizar. Madrid: Dykinson.

Madeyah, S. (2002). Non-Violent Resistance: Matching Means with Goals. Roaya, 16. Orig-

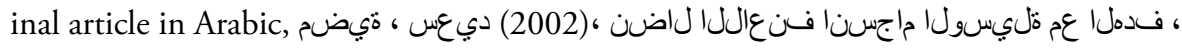

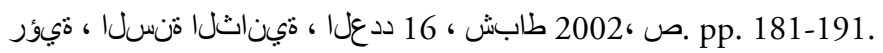

MacMahon, S. F. (2014). The Boycott, Divestment, Sanctions campaign: contradictions and challenges. Race and Class, 55(4), 65-81.

Mansour, A. (1988). The West Bank Economy: 1948-1984. In G. T. Abed, The Palestinian Economy: studies in development under prolonged occupation. London: Routledge.

Masalha, N. (2018). Palestine: A Four Thousand Year History. London: Zed Books.

McAdam, D. (1999). Political Process and the Development of Black Insurgency. Chicago: Chicago University Press.

Mishal, S. (1981). Nationalism through Localism: Some Observations on the West Bank Political Elite. Middle Eastern Studies, 17(4), 477-491.

Morton, A. D. (2007). Unravelling Gramsci. Hegemony and Passive Revolution in the Global Economy. London: Pluto Press.

Nazzal, H. (2010). Peaceful Resistance in International Conflict: Palestine as Case Study. Unpublished Master Thesis, Birzeit University.

Norman, J. M. (2010). The Second Palestinian Intifada. Civil Resistance. London and New York: Routledge. 
Qumsiyeh, M. (2011). Popular Resistance in Palestine: History of Hope and Empowerment. Ramallah: Muwaitin, The Palestinian Center for Democracy.

Pappe, I. (2014). Storia della Palestina Moderna. Una Terra due popoli. Torino: Einaudi.

Pfeffer, A. (2010). Mass Demonstration in Bil'in Marks Five Years of Protests Against West Bank Separation Fence. Haaretz. Retrieved from https://www.haaretz.com/1.5032984

Porath, Y. (1995). The Palestinian Arab National Movement 1918-1929. London: Frank Cass.

Qtait J. et al. (2006). Arab and Boycotting of Israel. Amman: Center for Middle East Studies. Original in Arabic, نامع،يئارسإةعطاقموبرعلا،طيطقداهج:

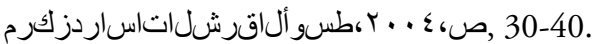

Randle, M. (1994). Civil Resistance. London: Fontana.

Reuters. (2017). Benjamin Netanyahu threatens to expel al-Jazeera from Israel. The Guardian. Retrieved from: https://www.theguardian.com/world/2017/jul/27/benjamin -netanyahu-threatens-to-expel-al-jazeera-from-israel

Rigby, A. (1991). Living the intifada. London: Zed Books.

Roberts, A. and Ash, T. G. (eds.) (2009). Civil Resistance and Power Politics: The Experience of non-Violence Action from Gandhi to the Present. Oxford: Oxford University Press.

Robinson, G. E. (1993). The Role of the Professional Middle Class in the Mobilization of Palestine Society: The Medical and Agricultural Committees. International Journal of Middle East Studies, 25(2), 301-26.

Rodman, K. A. (1994). Public and Private Sanctions against South Africa. Political Science Quarterly, 109(2), 313-34.

Roy, S. (1987). The Gaza Strip, A Case of Economic De-Development. Journal of Palestine Studies, $17(1)$, 56-88. 
RT (2017). University lecturer denied entry to Israel, banned for 10 years. Retrieved from https:// www.rt.com/uk/363194-israel-bans-soas-lecturer/

Said, E. (1992). The Question of Palestine. New York: Vintage Books.

Sayigh, Y. (1997). Armed struggle and the Search for State. The Palestinian National Movement 1949-1993. Oxford: Institute for Palestine Studies, Clarendon Press.

Schock, K. (2013). The practice and study of civil resistance. Journal of Peace Research, 50(3), 277-290.

Semelin, J. (1993). Unarmed Resistance against Hitler: Civilian Resistance in Europe 19391943. Westport: Praeger Publisher.

Sharp, G. (1973). The Politics of Nonviolent Action. Boston: Porter Sargent.

Sharp, G. (1980). Social Power and Political Freedom. Boston: Porter Sargent.

Spayd, L. (2017). An Op-Ed Author Omits His Crimes, and The Times Does Too. New York Times. Retrieved from https://www.nytimes.com/2017/04/18/public-editor/anop-ed-author-omits-his-crimes-and-the-times-does-too.html

Stein, L. R. \& Swedenburg. T. (2004). Popular Culture, Relational History, and the Question of Power in Palestine and Israel. Journal of Palestine Studies, 33(4), 5-20.

Tilley, V. (2005). The one-state solution. A Breakthrough for Peace in the Israeli-Palestinian Deadlock. Ann Arbor: The University of Michigan Press.

Turner, M. (2001). Creating 'Partners for Peace': The Palestinian Authority and the International Statebuilding Agenda. Journal of Intervention and State building, 5(1), 1-21.

Vinthagen, S. (2015). A theory of nonviolent action. How civil resistance works. London: Zed Books. 
Rings, W. (1982). Life with the enemy. Collaboration and resistance in Hitler's Europe 19391945. New York: Doubleday and Company.

Yousef, A. (1974). Haj Amin Al Husseini between Political Realism and Traditional Dogmatism. Najah University Journal, 2(2), 541-566.

\section{Interviews}

Anonymous journalist working for a European news agency, Ramallah, 20/5/2017. Interview conducted in English.

Ismail, Fawzi President of the Palestinian communities in Europe, Cagliari 7/10/2017. Interview conducted in Italian.

Khwairah, Sami, local journalist and activist, Nablus 14 July 2016. Interview conducted in Arabic.

Zaki, Abbas, Member of Fatah Central Committee, Ramallah 17/02/2017. Interview conducted in English. 